\title{
Natural hazards and First Nations community setting: challenges for adaptation
}

\author{
S. Kulshreshtha ${ }^{1}$, E. Wheaton ${ }^{2}$ \& V. Wittrock ${ }^{2}$ \\ ${ }^{I}$ Department of Bioresource Policy Business and Economics, \\ University of Saskatchewan, Canada \\ ${ }^{2}$ Saskatchewan Research Council, Canada
}

\begin{abstract}
Natural hazards are a common occurrence on the semi-arid prairies, both in terms of extreme dryness (droughts), and extreme moisture (floods). Although when such events occur, they generate devastating impacts on the economic and social system of any community, when that community happens to be a First Nations community, these challenges are further compounded by the regulations that govern these communities. The community selected for this investigation was the Kainai Blood Indian Reserve, Alberta, Canada. The impacts of past extreme weather events (droughts and floods) were serious for the people of the Reserve, although floods likely had the most immediate impacts on the residents. The response capabilities of emergency services were stressed, infrastructure, such as roads, was damaged and the potable water sources were compromised. The droughts appeared to have less direct impact on the residents of the Reserve because their water supply is from communal groundwater sources. Adaptations to the extreme events were seriously handicapped by regulations that create economic limitations faced by the Kainai Nation residents. These include: limited money transfers by the Federal government to the Nation, absence of property rights, lack of local economic opportunities, high unemployment rates, and relatively lower human capital (level of education and skills). Moreover, future adaptation measures will continue to be challenging unless government policies are changed to meet the requirements of KBIR and similar First Nations communities.
\end{abstract}

Keywords: First Nations community, Kanai blood tribe reserve, drought, flood, adaptation, government policy. 


\section{Introduction}

Natural hazards, such as droughts and excessive moisture, occur commonly on the Canadian prairies. These extremes often result in devastating impacts on the economic and social system as well as environmental conditions of communities. First Nations communities are faced with several challenges, and impacts of climatic extremes are adding to the burden. IWGIA [1] has suggested that for indigenous (First Nations) peoples, climate change and extreme events bring different kinds of risks, opportunities, threaten cultural survival and negatively impact indigenous human rights. Some of these risks may be a result of a different governance structure and other characteristics compared with the other (non-First Nations) communities. This reduces their adaptive capacity, thereby making them more vulnerable to climate change. Adaptation to these extremes is further complicated by regulations that govern First Nation communities. This paper addresses the convergence of these challenges, their implications, and hints at better preparation for such hazards.

The Kainai Blood Indian Reserve (KBIR) is the community of five tribes of the Blackfoot Confederacy that entered into a peace agreement (Treaty Seven) in 1877 with the Canadian and British Governments. Under this treaty, KBIR (and other First Nations communities) faces a different governance structure and other characteristics compared to those faced by non-First Nations communities. Therefore, their sensitivities, resilience and vulnerabilities are different. This difference warrants further understanding for its benefits and challenges for the objective of decreasing vulnerability for all communities and nations.

The KBIR was selected for this investigation as it is in an area that is already frequented by extremes of drought and excessive moisture. The primary objective of this study was to investigate the impacts of the 2001 to 2002 drought as well as the floods of 1995, 2002 and 2005 on the KBIR, with emphasis on water resources. All these investigations were subject to available information. An associated objective was to identify the nature of adaptation measures undertaken by the KBIR. The study methods included an updating and synthesis of previous work, including interviews and focus groups held for the Institutional Adaptations to Climate Change project (Diaz et al. [2]), as well as building upon other literature.

\section{Study region}

The KBIR encompasses an area of just over $1,400 \mathrm{~km}^{2}$ (over 356,000 acres). It is located in southern Alberta in the Palliser Triangle, the driest part of the Canadian Prairies, and therefore the people on the Reserve are exposed to extreme climatic events, such as floods and droughts. It is bordered by the St. Mary River on the east, by Belly River on the west, and by Oldman River on the north (Figure 1). Even though the Reserve has rivers on three sides, its potable water supply is from groundwater. Some residents have their own private wells, while others receive water from community wells, distributed by the Reserve Administration once per week and deposited into cisterns (Magzul [3]). 


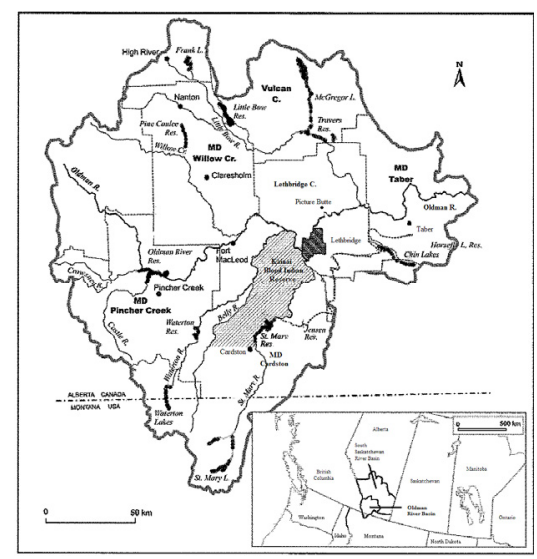

Figure 1: Map of the Kainai Blood Indian Reserve (adapted from Stratton [4]).

The population of the KBIR is subject to the definition used (Wittrock et al. [5]). There are two major sources of population estimates: The Census of Population organized by Statistics Canada, and the KBIR Administration. The KBIR Administration estimates the current population of the Band to be 9,000 to 10,000 people (Magzul [6]). However, Statistics Canada [7] estimated the 2006 population for the Reserve at 4,177 people. Although there are no official explanations for the discrepancy between the two estimates, the lower population count reflects the number of people living on the Reserve at the time of taking the census. The higher figure reflects registered members of the KBIR regardless of their place of residence.

The educational attainment of the Kainai Nation adults over 15 years of age is lower than that of a typical Albertan. Almost half of the KBIR people have no high school level education or beyond. As of 2006 , only $8 \%$ of their labour force had university degrees, compared with $21 \%$ for the province of Alberta (Wittrock et al. [5]). This lower level of education combined with the lack of employment opportunities on the Reserve contributes to a very high unemployment rate. In 2006, $23.6 \%$ of the total workers in the labour force were unemployed and the rate is especially high for young adults.

Agriculture is very prominent on the Reserve with 339,000 acres (137,200 hectares) in agricultural production. The Reserve has over 5,000 acres $(2,023$ hectares) of irrigated cropland and more than 18,000 acres (7,284 hectares) of irrigated hayland/grassland. Only $20 \%$ of the land is worked by Reserve members with the rest of the land being cash-leased to non-Reserve farmers. This cash-leasing arrangement for Reserve land began in the late 1980s after the last major drought (Magzul [8]). The Reserve also has a beef cattle operation, primarily grass fed, to make use of the available pasture land. Information on other sources of employment is sketchy.

This Reserve has numerous social issues that are indicative of many other Canadian First Nations communities, such as high unemployment, low income, 
an increasing population, and a complex set of regulations and policies of the Indian and Northern Affairs Canada.

\section{Characterization of extreme events}

The Fourth Assessment Report of the intergovernmental Panel on Climate Change (IPCC [9]) states that future increased risk in areas affected by drought is likely (i.e. 66\% probability of occurrence). Burke et al. [10] used the Hadley Centre Global Climate Model and found that by the second half of the twentyfirst century, droughts are slightly more frequent and much longer compared with present conditions. It is estimated that droughts longer than a year would triple in frequency, particularly in the Western North America.

During 1995 to 2006, extreme precipitation and subsequent flooding, as well as droughts occurred in southern Alberta, and the KBIR was subjected to both. The extended dry period began in the fall of 1998 and continued through the winter of 2001/2002. During that period the surrounding region had above average precipitation only in the fall of 1999 and winter of 2000/2001. The spring of 2002 had a dramatic increase in precipitation and a dramatic decrease in temperature. Extreme precipitation events occurred in June 2002, when Lethbridge received more than $251 \mathrm{~mm}$ and Cardston received $181.7 \mathrm{~mm}$, with 70 to $80 \%$ of the average rain for the month received over a three day period (June $8^{\text {th }}$ to $10^{\text {th }}$ inclusive).

\section{Socio-economic impacts of extreme events}

\subsection{Selected impacts of the 2001-2002 drought}

Although agriculture is a major land use on the Reserve, the 2001-2002 drought had very few negative impacts related to agriculture on the KBIR residents. This is because most of the agricultural lands are leased out to non-Reserve people. This is a safeguard since the cash lease rent is negotiated over a five year period, and is unaffected by occurrence of extreme events. The KBIR administration provides water to these irrigators. During the drought period water demand was higher than normal, and resulted in an increased cost of operation. Some small areas of dryland fields were also affected. In addition, there were other impacts of the drought (Table 1).

A major physical effect of the drought was reduced productivity of land and availability of water. Drought (lack of rainfall) affected forage production and was the primary cause of herd reduction. Approximately 700 cattle were on the KBIR prior to 2001, but decreased to between 200 and 300 head due to the drought and the BSE (Bovine Spongiform Encephalopathy) crisis (Magzul [8]). The KBIR Administration assisted livestock operations by securing feed, but the exact cost of this operation could not be ascertained. Lack of precise and appropriate data collected by the KBIR Band Council during the drought period (and following) resulted in making any meaningful estimate of the losses incurred by Band members. 
Table 1: $\quad$ Impacts of 2001-2002 droughts in the KBIR.

\begin{tabular}{|c|c|c|c|c|}
\hline \multirow[t]{2}{*}{ Affected Party } & \multicolumn{4}{|c|}{ Impacts } \\
\hline & Physical & Biological & Economic & Social \\
\hline $\begin{array}{c}\text { Local } \\
\text { Government }\end{array}$ & $\begin{array}{c}\text { Low groundwater } \\
\text { levels } \\
\text { Hard packed } \\
\text { roads } \\
\text { Higher cost of } \\
\text { providing } \\
\text { irrigation water }\end{array}$ & & $\begin{array}{c}\text { Increased water } \\
\text { delivery, resulted } \\
\text { in increased costs } \\
\text { Equipment damage } \\
\text { due to road } \\
\text { conditions }\end{array}$ & \\
\hline $\begin{array}{l}\text { Livestock } \\
\text { Producers }\end{array}$ & & $\begin{array}{c}\text { Low feed } \\
\text { supplies }\end{array}$ & $\begin{array}{c}\text { Increased cost of } \\
\text { feed }\end{array}$ & \\
\hline Dryland Farmers & Grass fires & & $\begin{array}{l}\text { Small returns due to } \\
\text { drought. }\end{array}$ & $\begin{array}{l}\text { Stress related to } \\
\text { dealing with fires }\end{array}$ \\
\hline $\begin{array}{l}\text { Residents of } \\
\text { KBIR }\end{array}$ & $\begin{array}{l}\text { Lack of water } \\
\text { Water levels in } \\
\text { wells were } \\
\text { declining and } \\
\text { some went dry } \\
\text { Cracked cisterns }\end{array}$ & & $\begin{array}{c}\text { Increased cost and } \\
\text { time required to } \\
\text { deliver water }\end{array}$ & $\begin{array}{c}\text { Hot weather may lead } \\
\text { to more violence } \\
\text { Hot weather causes } \\
\text { distress of the } \\
\text { elderly and those in } \\
\text { poor health }\end{array}$ \\
\hline Irrigated farming & Low water levels & & $\begin{array}{l}\text { Increased energy } \\
\text { and labour costs } \\
\text { for irrigation, } \\
\text { possibly }\end{array}$ & \\
\hline
\end{tabular}

The drought of 2001-2002 did have adverse effects on the operations of the Blood Tribe (BT) Works Department. Examples of these impacts included:

- Several grass fires were reported to have occurred during this period. These fires were costly (in terms of controlling them). In some cases, fire fighters from Lethbridge and Fort McLeod were brought to assist the local fire fighting crew.

- Ground was hard which affected machinery operations, particularly for road upkeep or repairs after flood damage. This resulted in higher labour costs.

- Groundwater was low and in some cases wells went dry. Data on number of dry wells were not collected and therefore, not known at this time. This necessitated delivery of water by trucks to these properties by the BT Works Department from the wells at the Standoff Capital of the KBIR). The destination of these trucks varied depending on locations of homes with dry wells. Homes that were affected the most were the ones without any cisterns.

- More water advisories were issued during the drought event of 2001, most of which involved boiling water.

- During the 2001 drought event, some cisterns and septic tanks were cracked and had to be repaired. Cost of replacing a cistern is estimated to be around $\$ 5,000$ per cistern. This indicates that the maintenance of such infrastructure is especially important to deal with droughts. 
- In the northern part of the Reserve, and near Fort Whoop Up, fields went very dry and created a dust problem. Information on the number of such events and their respective duration was not available. Although there were some minor health issues related to this, no major problems were encountered.

\subsection{Selected impacts of flooding}

Extreme precipitation and subsequent flooding appear to have more severe negative impacts on the community than droughts. An increased number of residents appear to have suffered damages as a result of floods because many homes and businesses were and are still located in flood-prone regions. In addition, infrastructure such as roads was damaged and the potable water sources were compromised due to contamination (Table 2). Major damages of the flood in 2005 included the following: (i) Road washouts, including culverts; (ii) Road damage; (iii) Flooded basements; (iv) Damaged personal belongings; (v) Moving people from their houses, and the cost of lodging in hotels or other suitable accommodation during the flooding period; (vi) Increased stress level among those affected; (vii) Treatment of the well water at a cost of $\$ 4,000$ per treatment; (viii) Impact on the cropland, and (ix) Reduced fishing in the river due to high river level.

During the flood of 2005 many homes were affected. According to Blood Tribe Housing Department almost half of the homes were damaged by this flood

Table 2: $\quad$ Selected impacts of flooding events in the KBIR.

\begin{tabular}{|c|c|c|c|c|}
\hline \multirow{2}{*}{$\begin{array}{l}\text { Affected } \\
\text { Party }\end{array}$} & \multicolumn{4}{|c|}{ Impacts } \\
\hline & Physical & Biological & Economic & Social \\
\hline $\begin{array}{c}\text { Local } \\
\text { Government }\end{array}$ & $\begin{array}{c}\text { Flooding resulted in } \\
\text { potable water being } \\
\text { compromised } \\
\text { Houses were flooded due } \\
\text { to location and high } \\
\text { water table } \\
\text { Housing stock has } \\
\text { deteriorated due to the } \\
\text { floods. }\end{array}$ & $\begin{array}{c}\text { Mold in } \\
\text { basements }\end{array}$ & $\begin{array}{c}\text { The } 2002 \text { floods } \\
\text { caused } \$ 6.6 \\
\text { million in damage } \\
\text { to infrastructure } \\
\text { and housing } \\
\text { The } 2005 \text { flood costs } \\
\text { were } \$ 8.6 \text { million. }\end{array}$ & $\begin{array}{l}80 \text { people } \\
\text { were } \\
\text { displaced } \\
\text { due to } \\
\text { flooding }\end{array}$ \\
\hline $\begin{array}{l}\text { Residents of } \\
\text { KBIR }\end{array}$ & $\begin{array}{c}\text { Flooded homes } \\
\text { Water supplies put at risk }\end{array}$ & $\begin{array}{c}\text { Contamination } \\
\text { of potable water } \\
\text { supplies from } \\
\text { sewage septic } \\
\text { tanks }\end{array}$ & $\begin{array}{l}\text { Increased income } \\
\text { potential }\end{array}$ & $\begin{array}{c}\text { People } \\
\text { stranded due } \\
\text { to flood } \\
\text { Health issues }\end{array}$ \\
\hline $\begin{array}{c}\text { Local } \\
\text { Businesses }\end{array}$ & Flooding of oil well sites & & & \\
\hline $\begin{array}{c}\text { Irrigated } \\
\text { Agriculture }\end{array}$ & & Flooded fields & $\begin{array}{c}\text { Flooded a couple of } \\
\text { pump houses and } \\
\text { damaged some of } \\
\text { the pumps }\end{array}$ & \\
\hline $\begin{array}{l}\text { Livestock } \\
\text { Producers }\end{array}$ & & $\begin{array}{l}\text { Lost livestock in } \\
\text { the } 1995 \text { flood }\end{array}$ & & \\
\hline
\end{tabular}


(Wittrock et al. [5]). Of the almost 1,218 homes, some 600 of these were affected. Major damage came through flooded basements and sewer backups.

The total damage to the homes was estimated at $\$ 6.5$ million. However, a portion of this cost was reduced through some compensation received from the provincial government under the Alberta Emergency Program. Limited assistance for relocation of homes away from the flood plain was also received from Indian and Northern Affairs Canada.

Mold is a big problem after any flood event, as it affects human health. Although, no direct association was made between water supply, mold, and disease incidence during these periods, the presence of mold in some homes added further stress and health risks for some of the households during and following flood periods. Furthermore, it adds to the costs required to address the problem.

On the positive side, although flooding is costly to the Blood Tribe Administration, it does increase number of people temporarily employed on the Reserve, and brings income to the people. In addition, contractors (people) undertaking flood damage repairs or selling carpets do better business due to these events.

\section{Adaptive capacity and vulnerability of the community}

\subsection{Factors affecting adaptation}

Vulnerability of a community and the people within it to climate change is generally perceived as the damage or harm to a socio-economic system. Adger [11] defines it as "the state of susceptibility to harm from exposure to stresses associated with environmental and social change and from the absence of capacity to adapt." The vulnerability, in this context, is a function of the degree of exposure of a system to climatic hazards and of its adaptive capacity (the degree to which adjustments in practices, process or structures can moderate or offset the potential for damage or take advantage of opportunities created by a given change in climate). Thus vulnerability can be equated to the remaining level of damage from an extreme event after various types of adaptation measures are undertaken. Whether one undertakes these measures depends on the adaptive capacity of the individual or the group of individuals.

A number of factors can be identified that affect the adaptive capacity. One such factor is governance. Kelly and Adger [12] have identified such factors as landlord/peasant fiduciary relations, locally organized collective action networks and worldviews as key to understanding stakeholder vulnerability and adaptive capacity. In the context of KBIR these factors include: (i) Lack of property rights to individuals. This is an obstacle to many individual members of the KBIR to initiate actions. Included here is the fact that individuals do not have a clear title to ownership of the land or homes. This makes them particularly limited in terms of access to capital resources, such as obtaining loans for repairs. (ii) Limited or no rights to female spouses living on the Reserve, which affects their initiative for undertaking adaptive actions. (iii) Occupancy rights for some members of the 
Reserve, which affects their options for location of their residence; and (iv) Federal government is the sole source of funding for many capital projects on the KBIR. This makes the community more vulnerable to government institutions which may or may not react in time for taking proper adaptive measures. The KBIR has begun to address issues of governance, since these increase their vulnerability to stressors (including floods) (Marito [13]).

In addition to governance, people or community's adaptive capacity is constrained by many socio-economic factors. It is determined by personal and community-level social attributes that may result in increased susceptibility to external impacts. As such, vulnerability is largely socially-constructed and influenced by factors such as lower income, lower educational attainment, lack of familiarity with similar events, lack of knowledge of possible adaptation measures, and access to resources (Yohe and Tol [14]).

\subsection{Nature of Adaptation in the KBIR}

The KBIR residents and the Band Council have made several types of adaptations to climate change induced by extreme events, as summarized in Table 3. With respect to drought, one of the major actions undertaken by the band previously was leasing out the irrigated lands to non-KBIR farmers in the neighbourhood. This decision was made in response to an earlier drought (Magzul [6]). While cash leases of land allow the band and various members to have guaranteed income, it results in lack of work for the KBIR workers. The future vulnerability of the KBIR to drought could increase because the Band Council has decided to begin the process of reducing the amount of cash-leased

Table 3: Types of adaption measures undertaken by KBIR in response to droughts.

\begin{tabular}{|c|c|c|c|}
\hline \multirow{2}{*}{$\begin{array}{c}\text { Type of } \\
\text { Respondent }\end{array}$} & \multicolumn{3}{|c|}{ Adaptations } \\
\hline & Successful & Not Successful & Comments \\
\hline $\begin{array}{c}\text { Local } \\
\text { Government }\end{array}$ & Boil water advisories & & \\
\hline $\begin{array}{l}\text { Livestock } \\
\text { Producers }\end{array}$ & $\begin{array}{c}\text { Sold large number of cattle. } \\
\text { Bought feed } \\
\text { Obtained water for cattle } \\
\text { via pipeline from river }\end{array}$ & & \\
\hline $\begin{array}{l}\text { Dryland } \\
\text { Farmers }\end{array}$ & $\begin{array}{l}\text { Leased land } \\
\text { Because of the drought in } \\
\text { the } 1980 \text { s, a large portion } \\
\text { of land was turned back } \\
\text { to the Reserve from } \\
\text { individual tribe members }\end{array}$ & & $\begin{array}{c}\text { Changed the way the land } \\
\text { was leased after the } 1988 \\
\text { drought. } \\
\text { Work for tribe members }\end{array}$ \\
\hline $\begin{array}{l}\text { Residents of } \\
\text { KBIR }\end{array}$ & $\begin{array}{l}\text { Conserve water } \\
\text { where possible. } \\
\text { KBIR members with } \\
\text { occupancy rights cash- } \\
\text { lease their land to non- } \\
\text { native farmers. }\end{array}$ & $\begin{array}{c}\text { Less success in } \\
\text { moving homes } \\
\text { from flood zone } \\
\text { due to occupancy } \\
\text { rights }\end{array}$ & $\begin{array}{c}\text { Water conservation is partly } \\
\text { due to infrastructure } \\
\text { difficulties }\end{array}$ \\
\hline
\end{tabular}


land (Swihart [15]). While this may be a right step for improving the employment conditions on the Reserve, it will make the KBIR more vulnerable to extreme climatic events.

The KBIR residents, in 2001-2002, were somewhat buffered from drought by their use of groundwater. However, some of the economic impacts of these events could not be determined due to lack of data and information gathering on a continual basis; for example, it is not known if the groundwater levels were negatively affected by the drought because water supply and demand are not monitored.

Adaptation measures in response to floods are presented in Table 4. Floods require adaptation measures to be implemented very quickly, including moving people to safe places. Medium-term adaptation measures applied included checking water quality on a regular basis and imposing boil water advisories, as needed. Longer-term adaptation strategies included an emergency response task force and a plan was put in place after the 1995 flood. The process and the plan were tested and refined in 2002 and 2005 (Magzul [6]). Other medium- and long-term adaptation strategies used included insurance and federal government compensation for lost property.

The Blood Tribe Administrative Departments have begun to survey the Reserve in order to locate the homes in less flood-prone areas. The same surveys are proposed to be used for designing and locating roads to various homes on the Reserve. Under this plan, no new houses would be permitted to be built in the flood plain and each new house would be required to have proper drainage (Magzul [6]). However, some Kanai Nation members have occupancy rights on land that is only on the flood prone land and may not have the option of locating their homes in areas with less risk of flooding.

Since the 2002 floods, the KBIR's Department of Public Works has been upgrading some roads with more compaction and better drainage to prevent washouts during heavy precipitation events. Boil-water advisories were issued to Reserve residents because of possible contamination from flood waters.

Although funding from Indian and Northern Affairs Canada has been received, it does not cover the total cost of renovating these damaged homes. Funding trickles down in smaller amounts. Thus, among factors that inhibit adaptation of extreme events on the KBIR is the policy of the federal government. By controlling the release of financial resources to the KBIR, it controls the pace of adjustment. Although these funding releases are somewhat responsive to the occurrence of extreme events, they are not very timely and definitely not adequate.

\section{Challenges of the new climatic extremes}

The KBIR is in an area that is relatively hotter and drier than other parts of the prairie ecozone. This aridity could become worse in the future and is likely already experiencing this trend. Recent droughts and excessive moisture events can be considered harbingers of the extremes likely to occur. Bonsal et al. [16] reviewed work regarding future droughts in the Canadian Prairies and elsewhere. 
Table 4: $\quad$ Selected adaptation measures undertaken in response to flooding on the KBIR.

\begin{tabular}{|c|c|c|c|}
\hline \multirow{2}{*}{$\begin{array}{c}\text { Type of } \\
\text { Respondent }\end{array}$} & \multicolumn{3}{|c|}{ Adaptations } \\
\hline & Successful & Not Successful & Comments \\
\hline $\begin{array}{c}\text { Local } \\
\text { Government }\end{array}$ & $\begin{array}{c}\text { Installed water treatment } \\
\text { facility } \\
\text { New well for one of the } \\
\text { communities } \\
\text { Houses moved to higher } \\
\text { ground in town site resulted } \\
\text { in less damage in recent } \\
\text { flood } \\
\text { Development of a general } \\
\text { disaster plan } \\
\text { Each new house built has soil } \\
\text { test and proper drainage } \\
\text { Imposed boil water advisory } \\
\text { during flood events } \\
\text { Tests water quality on regular } \\
\text { basis } \\
\text { Better maintenance of road } \\
\text { infrastructure }\end{array}$ & $\begin{array}{c}\text { Houses built on flood } \\
\text { plain, some residents } \\
\text { do not want to move } \\
\text { while others do not } \\
\text { have other property to } \\
\text { move to } \\
\text { Lack of housing } \\
\text { Lack of funds } \\
\text { Improperly installed } \\
\text { weeping tiles } \\
\text { Need to update disaster } \\
\text { response plan } \\
\text { Boil water advisories } \\
\text { created problems for } \\
\text { residents including } \\
\text { cost, time and } \\
\text { inconvenience }\end{array}$ & $\begin{array}{c}\text { Reserve builds only } \\
20 \text { new houses } \\
\text { per year but } \\
\text { demand and need } \\
\text { is much greater } \\
\text { It is not known if } \\
\text { the flood victims } \\
\text { were } \\
\text { compensated by } \\
\text { Indian \& } \\
\text { Northern Affairs }\end{array}$ \\
\hline $\begin{array}{l}\text { Emergency } \\
\text { Response } \\
\text { Organization } \\
\text { s }\end{array}$ & $\begin{array}{c}\text { Closed flooded roads } \\
\text { Rescued stranded citizens } \\
\text { Preparing for more frequent } \\
\text { floods through acquisition } \\
\text { of more equipment }\end{array}$ & & \\
\hline $\begin{array}{c}\text { Residents of } \\
\text { KBIR }\end{array}$ & $\begin{array}{l}\text { Drank bottled water during } \\
\text { flood events }\end{array}$ & $\begin{array}{c}\text { Cost and inconvenience } \\
\text { of bottled water. } \\
\text { Cannot or do not want } \\
\text { to move from flood } \\
\text { prone regions. }\end{array}$ & \\
\hline $\begin{array}{c}\text { Local } \\
\text { Businesses }\end{array}$ & Have contingency flood plan & & \\
\hline $\begin{array}{l}\text { Irrigation } \\
\text { Land and } \\
\text { Irrigation } \\
\text { Farmers }\end{array}$ & $\begin{array}{l}\text { Fixed the pumps } \\
\text { Crop insurance }\end{array}$ & Crop insurance & $\begin{array}{c}\text { Were able to recover } \\
\text { costs through } \\
\text { "disaster services" } \\
\text { Minimize buying } \\
\text { insurance due to } \\
\text { high rates. }\end{array}$ \\
\hline
\end{tabular}

All Global Climate Models project future increases of summer continental interior drying and associated risk of droughts. A main reason for this greater risk is the increasing temperatures and resulting potential evapotranspiration not being compensated for by projected changes in precipitation and longer warm seasons.

It seems strange, but with the enhancement of the global hydrological cycles, not only does drought become worse, but extreme precipitation and associated excessive moisture and flooding also can increase. IPCC [9] states that the frequency of heavy precipitation amounts has increased over most land areas and that this pattern is consistent with the observed increases of atmospheric water vapour. In summary, the risk of serious droughts and excessive moisture 
conditions appears to be increasing. One of the greatest risks of future climate change is the effects on water availability (Sauchyn and Kulshreshtha [17]). Multi-year droughts and excessive moisture are especially challenging and would be devastating without considerable preparation. What does the changing risk mean for KBIR and other First Nations communities?

\section{Conclusion}

Although extreme events can be devastating to a community, the KBIR was fairly adapted to the 2001-2002 drought as it suffered few damages. However, the community is highly vulnerable in other aspects and perhaps even to longer and larger area droughts. Flooding caused more immediate damage to the residents and to the KBIR administration. Adaptation to these extremes is complicated initially by the lower adaptive capacity of the community, but also by higher level government rules and regulations that govern the planning for such adaptations. These rules make planning for the extreme events as well as adaptation to them very challenging. Moreover, future adaptation measures will continue to be challenging unless government policies and institutions evolve to meet the requirements of KBIR and similar First Nation communities. Lessons of adaptation and lack of adaptation from past droughts and excessive moisture events should be used to proactively design, test, and improve adaptation strategies.

\section{References}

[1] IWGIA (International Work Group for Indigenous Affairs), Conference on Indigenous Peoples and Climate Change - Conference Report, International Work Group for Indigenous Affairs, Copenhagen. February 21-22, 12 pp. 2008.

[2] Diaz, H., Hadarits, M. \& Barrett-Deibert, P. IACC, Institutional Adaptations to Climate Change Project, Comparative Study of Dryland River Basins in Canada and Chile. Final Report. Canadian Plains Research Center: University of Regina. 92 pp., 2009.

[3] Magzul, L. Report on the Blood Tribe (Kainai Nation): Community Vulnerabilities. University of British Columbia. Vancouver, British Columbia. 32 pp., 2007.

[4] Stratton, E. K. 2005. "Local Involvement in Water Management and Adaptive Capacity in the Oldman River Basin, Alberta." Master's thesis. University of Guelph, Guelph.

[5] Wittrock, V., Kulshreshtha, S., Magzul, L., \& Wheaton, E. Adapting to Impacts of Climatic Extremes: Case Study of the Kainai Blood Indian Reserve, Alberta. Saskatchewan Research Council (SRC), Saskatoon, 94 pp., 2008.

[6] Magzul, L. The Blood Tribe: Adapting to Climate Change, Prairie Forum. 34, pp. 289-309, 2009. 
[7] Statistics Canada, 2006 Community Profiles - All - Blood 148, Alberta (Indian Reserve). On-Line. http://www.12.statcan.ca/english/profile01 /CP01/Details/Print.cfm?Lang=E\&Geo1=CSD.

[8] Magzul, L. "Fieldnotes" Community vulnerability Assessment of the Blood Indian Reserve, Institutional Adaptation to Climate Change Project. University of Regina, Regina, Saskatchewan, 2005.

[9] IPCC - Intergovernmental Panel on Climate Change, Climate Change 2007 - Impacts, Adaptation and Vulnerability. ed. M. Parry, O. Canzini, J. Palutikof, P. Van der Linden \& C. Hanson. Cambridge, UK: Cambridge University Press, 2007.

[10] Burke, E., Brown, S., \&. Christidis, N. Modeling the recent evolution of global drought and projections for the twenty-first century with the Hadley Centre climate model. Journal of Hydrometeorology. 7, pp. 1113-1125, 2006.

[11] Adger, W.N. 'Vulnerability', Global Environmental Change. 16, pp. 268281, 2006.

[12] Kelly, P. M., \& Adger, W. N. (2000). Theory and practice in assessing vulnerability to climate change and facilitating adaptation. Climatic Change. 47, pp. 325-352, 2000.

[13] Morito, B. Ethics of Climate Change: Adopting an Empirical Approach to Moral Concern. Human Ecology Review. 17, pp. 106-116, 2010.

[14] Yohe, G., and Tol, R. Indicators for social and economic coping capacity Moving toward a working definition of adaptive capacity. Global Environ. Change. 12, pp. 25-40, 2002.

[15] Swihart, R. Alberta First Nations Band Gets Serious About Farming, The Western Producer. 9 January, p. 62, 2009.

[16] Bonsal, B., Wheaton, E., A. Chipanshi, C. Lin, D. Sauchyn, L. Wen. Drought Research in Canada: A Review. Atmosphere-Ocean, pp.1-17, 2011.

[17] Sauchyn, D. \& Kulshreshtha, S. The Prairies. In D. Lemmen, F. Warren, E. Bush \& J. Lacroix (eds.). From Impacts to Adaptation: Canada in a Changing Climate 2007. Ottawa: Government of Canada (Natural Resources Canada), pp. 275-328, 2007. 